\title{
Do English language learners know collocations?
}

\author{
Matgorzata Martyńska \\ Institute of Linguistics, Adam Mickiewicz University \\ ul. Międzychodzka 5, 60-371 Poznań, POLAND \\ bonitadpf.pl
}

\begin{abstract}
This paper has a twofold purpose. First, to present the level of collocational competence among intermediate learners of the English language and to answer the question to what degree they know English collocations. With this goal in mind, a group of high school students was submitted to a test on collocation, whose results are shown in Section 2 of this paper. Second, to survey different linguistic attitudes towards the phenomenon of collocation and its categorization, as well as to emphasize the role of collocation in the process of second language learning.
\end{abstract}

\section{Introduction}

This paper is primarily concerned with a general concept of collocation, its applicability and usefulness in the process of teaching foreign languages as well as problems it may cause for learners. With this goal in mind, there has been done research into the collocational competence of intermediate English learners from a Wagrowiec high school. The present linguistic study of vocabulary and its central role in acquiring language competence has changed radically in comparison with the previous views. Learning a foreign language used to be predominantly associated with learning its grammatical structures, with lexis being restricted to the area barely large enough to present these structures. In short, the significance of vocabulary in the learning process was played down while the function of grammar was regarded superior. It was not until Lewis [1994], who developed the Lexical Approach theory, that the pivotal role of lexis as the basics of any language became highly respectable. 


\section{Various definitions of collocation and their classification}

\subsection{The origin of the word 'collocation'}

This term was first introduced by Firth [1957] to define a combination of words associated with each other, for example to take a photo : zrobić zdjęcie. It is an English equivalent of the term 'związek łączliwy' used by Polish linguists. The term 'collocation' has its origin in the Latin verb 'collocare' which means 'to set in order/to arrange'. Skorupka [1967] defines 'związek łączliwy' as a highly cohesive combination of words which are not lexicalized, that is the meaning of the whole combination is a sum of the meanings of its individual elements, for example dobry, róźowy, świetny, zly humor. He points out that co-occurrence of some words can be determined and in some cases restricted by their meaning. The adjective gniady refers only to horses so its collocational range is quite limited. Kania and Tokarski [1984] add that replacing one or two elements of collocation with a limited number of words is admissible, e.g. rościć prawo/pretensję.

\subsection{The lexical approach.}

It is Firth who is widely regarded as the father of collocation and the developer of a lexical and the most traditional approach to this phenomenon. Advocates of the lexical approach claim that the meaning of a word is determined by the co-occuring words. Consequently, lexis is considered to be independent and separable from grammar. Thus, a part of the meaning of a word is the fact that it collocates with another word. However, those combinations are often strictly limited, e.g. make an omlette but do your homework while both the verbs do and make have only one Polish equivalent robić. One of the Firth's revolutionary concepts was to perceive lexical relations as syntagmatic rather than paradigmatic ones. Sinclair [1966] and Halliday [1966] are Firth's followers.

For Halliday, collocations are examples of word combinations; he maintains that collocation cuts across grammar boundaries. For instance, he argued strongly and the strength of his argument are grammatical transformations of the initial collocation strong argument. In his works he highlights the crucial role of collocations in the study of lexis.

Sinclair introduces the following terminology: an item whose collocations are studied is called a 'node'; the number of relevant lexical items on each side of a node is defined as a 'span' and those items which are found within the span are called 'collocates'. Later on Sinclair slightly changes his attitude forming an 'integrated approach' and dismisses the previous idea that lexis is rigidly separated from grammar. In this new approach both the lexical and grammatical aspects of collocation are taken into consideration. As a result, Sinclair [1991] divides collocations into two categories: the 'upward' and 'downward' collocations. The first group consists of words which habitually collocate with the words more frequently used in English than they are themselves, e.g. back collocates with at, down, from, into, on, all of which are more frequent words than back. Similarly, the 'downward' collocations are words which habitually collocate with words that are less frequent than they are, e.g. words arrive, bring are less frequently occurring collocates of back. Sinclair makes a sharp distinction between those two categories claiming that the elements of the 'upward' collocation (mostly prepositions, adverbs, conjunctions, pronouns) tend to form grammatical frames while the elements of the 'downward' collocation (mostly nouns and verbs) by contrast give a semantic analysis of a word. 


\subsection{The semantic approach.}

This approach goes beyond the sheer observation of collocations and tries to determine their specific shape. Its supporters attempt to examine collocations from the semantic point of view, also separately form grammar. Their main goal is to find out why words collocate with certain other words, e.g. why we can say blonde hair but not blonde car. This question still represents a challenge for linguists today.

\subsection{The structural approach.}

According to this approach, collocation is determined by structure and occurs in patterns. Therefore, the study of collocation should include grammar [Gitsaki 1996], which contrasts with the two aforementioned approaches: the lexical and semantic ones. Lexis and grammar cannot be separated and, consequently, two categories are defined: lexical and grammatical collocation, which represent two distinctive but related aspects of one phenomenon. Grammatical collocations usually consist of a noun, an adjective or a verb plus a preposition or a grammatical structure such as 'to+infinitive' or 'that-clause', e.g. by accident, to be afraid that. Lexical collocations do not contain grammatical elements, but are combinations of nouns, adjectives, verbs, adverbs [Bahns 1993].

Benson, Benson and Ilson [1997] define collocation as specified, identifiable, non-idiomatic, recurrent combinations. In their dictionary they divide them into two groups: grammatical and lexical collocations. The first category consists of the main word (a noun, an adjective, a verb) plus a preposition or 'to+infinitive' or 'that-clause' and is characterized by 8 basic types of collocations:

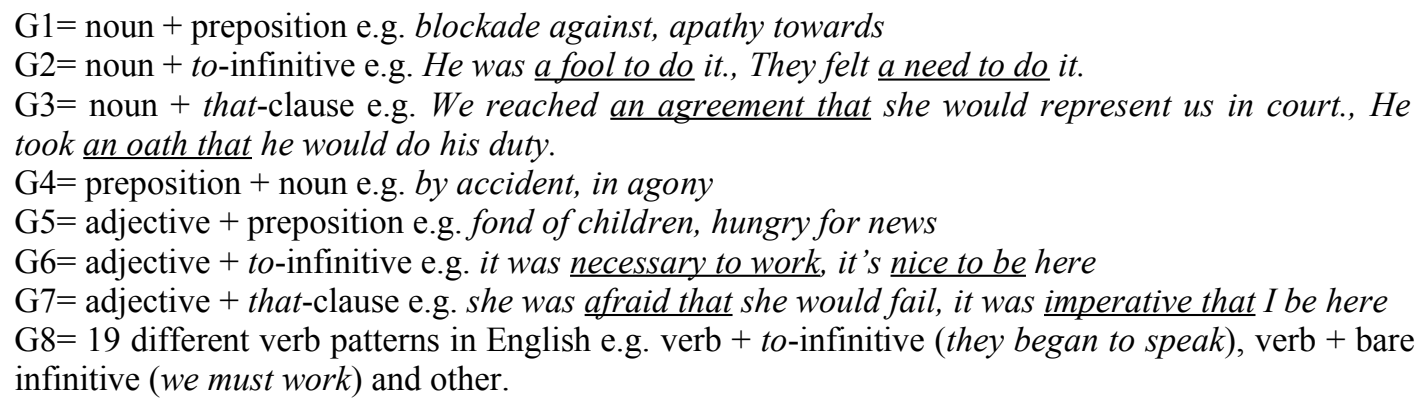

Lexical collocations do not contain prepositions, infinitives or relative clauses but consist of nouns, adjectives, verbs and adverbs. There are 7 types of them:

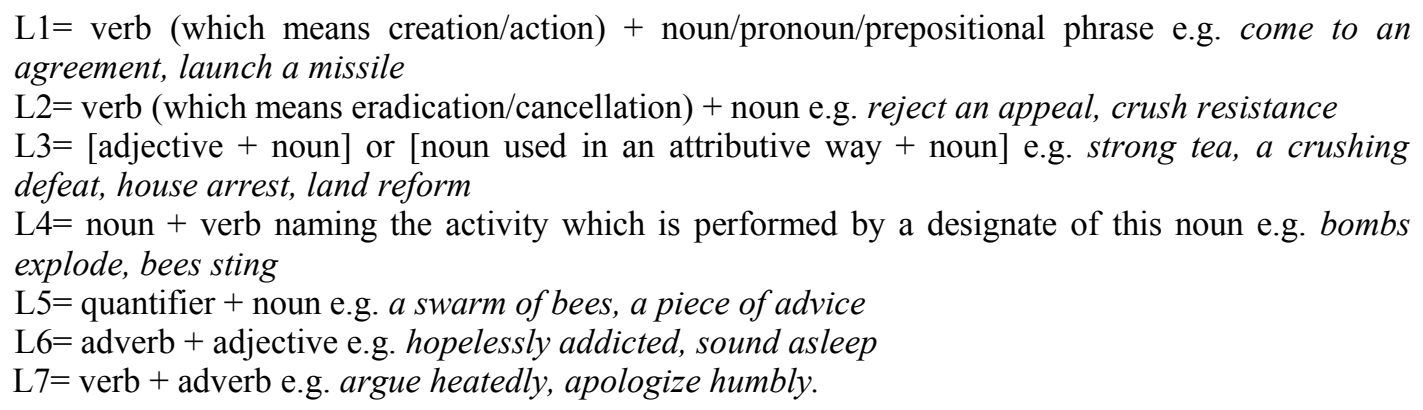

Kjellmer [1990] tries to establish to what extent individual word classes are 'collocational' or 'non-collocational' in character. The results of his research show that articles, prepositions, singular and mass nouns as well as the base forms of verbs were collocational in their nature whereas adjectives, singular proper nouns and adverbs were not. Kjellmer claims that English words are scattered across a continuum which extends from those items whose contextual company is entirely predictable to those whose contextual company is entirely unpredictable. According to his results, most words tend to appear towards the beginning of the continuum, which can also be described as a scale of fixedness of collocation. Then it extends from totally free, unrestricted combinations to totally fixed and invariable ones. Kjellmer's theory about 
collocational continuum is relevant also in regard to lexical collocations although they are linked together in a different way than grammatical ones, that is they refer more to semantics.

Lewis [2000] argues that most collocations are found in the middle of this continuum, which means that there are very few 'strong' collocations. He makes a distinction between 'strong' collocation e.g. avid reader, budding author; 'common' collocation which makes up numerous word combinations, e.g. fast car, have dinner, a bit tired and 'medium strong' one, which in his view account for the largest part of the lexis a language learner needs, e.g. magnificent house, significantly different. Hill adds one more category - 'unique' collocation such as to foot the bill, shrug one'shoulders. In terms of the strength of collocation, it is worth noting that it is not reciprocal, which means that the strength between the words is not equal on both sides, e.g. blonde and hair. Blonde collocates only with a limited number of words describing hair colour whereas hair collocates with many words, e.g. brown, long, short, mousy. It happens very often that the bond between the words is unilateral, e.g. in the phrase vested interest, vested only ever collocates with interest but interest collocates with many other words.

Hunston [1997] concluded that there are correlations between grammatical patterns and lexical meaning. All words can be represented by specific patterns and the meanings of words which share patterns have a lot in common. That means that a word has a specific meaning when it co-occurs with a certain word. This hypothesis is followed by Hoey [2000], who maintains that some meanings of the same word have their own grammatical patterns, which is called 'colligation'. This concept started by Firth is concerned with relationship between grammatical classes, whereas collocation is concerned with the words which belong to these grammatical classes. Grammatical pattern [verb+to-infinitive] is an example of colligation and [dread+think] is an example collocation of this colligation. In short, colligation defines the grammatical company and interaction of words as well as their preferable position in a sentence.

Another key point in the study of collocation started by Firth is the notion of syntagmatic (horizontal) as opposed to paradigmatic (vertical) relationship between its elements. In the syntagmatic dimension we can clearly see the relationship between linearly lined up words, which make up an individual syntactic unit, here a collocation. In the sentence: It writhed on the floor in agonizing pain the syntagmatic relationship is the one between the words: writhed, floor, agonizing and pain, whereas the paradigmatic relationship is between a word and a group of words which can replace it in this sentence:

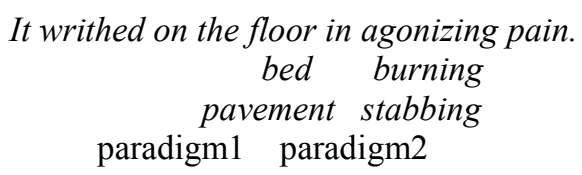

Lewis [1994] defines collocation as a subcategory of multi-word items, made up of individual words which habitually co-occur and can be found within the free-fixed collocational continuum. In his opinion, they differ from another important subcategory of multi-word items called institutionalized expressions because collocations tell more about the content of what a language user expresses rather than what the language user is doing, e.g. apologizing or denying. Lewis [1997] points out that collocation is not determined by logic or frequency but is arbitrary, decided only by linguist convention. Dzierżanowska [1988] adds that words that make up collocation do not combine with each other at random. Collocation cannot be invented by a second language user. A native speaker uses them instinctively, e.g. a Polish native speaker knows that it is possible to say wywierać/mieć wpływ but not okazywać/odgrywać. In every language collocations comply with the rules characteristic of that language and therefore they cause serious problems both for learners and translators, e.g. osiagnać cel has two English equivalents achieve/reach an aim but osiagnać porozumienie can be translated with the verb reach but not achieve-reach an agreement. Consequently, collocations must be memorized or looked up in an adequate dictionary.

Celce-Murcia [1991] defines collocation as a co-occurrence of lexical items in combinations, which can differ in frequency or acceptability. Items which collocate frequently with each other are called 'habitual', e.g. tell a story, whereas those which cannot co-occur are called 'unacceptable', e.g. *powerful tea instead of strong tea. 
Similarly, in Carter's view [1987], collocation is a group of words that recurrently co-occur in a language. He agrees with Benson that there are grammatical collocations which result from grammatical relationship between the words and lexical collocations which result not only from grammatical relationship, but most of all from co-occurrence of lexical units in a specific company. The total number of words which can collocate with an X word is called a 'cluster' of X. $\mathrm{He}$ also points out that certain elements of a cluster are more central than other, which means that they are more likely to co-occur with X. Carter divides collocations into four categories, depending on how restricted they are: 'unrestricted', which collocate freely with a number of lexical items, e.g. take a look/a holiday/a rest/a letter/time/notice/a walk; 'semi-restricted', in which the number of adequate substitutes which can replace the elements of collocation is more limited, e.g. harbour doubt/grudges/uncertainty/suspicion. The other two categories include 'familiar' collocations whose elements collocate on a regular basis, e.g. unrequited love, lukewarm reception and 'restricted' collocations which are fixed and inflexible, e.g. dead drunk, pretty sure. Carter distinguishes between 'core' and 'non-core' words claiming that the more core a lexical item is, the more frequently it collocates. Core words are more central in a language than other, non-core words and that is why the non-core words can be defined or replaced by the core items, e.g. eat is a core word for gobble, dine, devour, stuff, gormandize because its meaning is the basic meaning of every item from the group but this relationship is not reciprocal. In Carter's view, words are scattered across a core-non-core continuum and their position on this scale determines their collocability. The nearer to the core end of the continuum a word is, the more frequently it collocates, e.g. bright $>$ radiant $>$ gaudy:

\section{bright: sun/light/sky/idea/colour/red/future/prospects/child radiant: sun/light/smile gaudy: colour}

According to a dictionary definition [Szulc1984], collocation is an ability of lexical items to build steady, conventionalized syntagmatic relationship with other words, e.g. putrid, rotten, rancid and addled are synonyms which designate rotten food but they collocate only with a limited number of words: putrid fish, rancid butter/oil, addled eggs, rotten fruit. Individual collocations are determined by the lexical system of a language and can result from historical changes, e.g. in Polish prać rzeczy but myć ręce. The difference is caused by the fact that prać used to mean bić, e.g. /offensive/ sprać kogoś, prać po mordzie. Such collocations became a part of the lexical system on the basis of linguist convention, which results in collocational differences between languages, although a phenomenon of isomorphism sometimes occurs, e.g. in Polish od czasu do czasu and in English from time to time. The most general and commonly accepted definition describes collocation as a lexical company that a lexical item keeps.

According to Oxford Collocations Dictionary [2002], collocation is a means of combining words in a language to produce natural-sounding speech and writing. Incorrect combinations such as heavy wind or strong rain do not sound naturally in English. Apart from the prevalent grammatical/lexical distinction, the authors also mention 'word' collocation, none of whose elements can be replaced even with its synonym, e.g. small fortune but not *little fortune and 'category' collocation whose elements can collocate with any items of a precisely determined group of words. This group can be quite large and its elements- predictable because they make up the same category, e.g. measurements of time for a noun walk: five minutes' walk/three-minute walk.

\subsection{Conclusions.}

Although collocation has become the subject of a linguistic study only recently, it attracts a growing interest from numerous linguists and is defined in various ways. Accordingly, there is no exhaustive and uniform definition or categorization of collocation. Therefore, it tends to be one of the most problematic and error-generating area of vocabulary, especially for second language learners, which can be clearly seen from the results of the tests analyzed in Section 2 of this paper. 


\section{Collocational competence of intermediate English learners.}

\subsection{The subject of this study.}

This research aims at identifying the level of collocational competence of intermediate English learners. Fiftythree Wagrowiec high school fourth-year students were submitted to a 2-page test, whose results form the basis of this analysis. They were given four different tasks which involved:

I- matching words from column A with their collocates from column B and giving their Polish equivalents

1) Przyporządkuj numer z kolumny A do odpowiedniego wyrazu lub wyrażenia z kolumny $B$ oraz napisz ich polskie odpowiedniki w nawiasach.

1 - to make

2 - to bite [

3 - to mind [

4 - high-heeled [.

5 - part-time [

$6-$ job [

7 - ozone [

8 - heart [

9 - car [

10 - a bucket

11 - seriously [....

12 - take it [
A



B



II- completing 3 missing collocates of the central word which belong to specified parts of speech and giving the Polish equivalent of the central word

2) Dopisz 3 wyrazy, które mogą współwystępować z podanym wyrazem oraz jego polski odpowiednik:

a. dopisz rzeczownik rzeczownik



d. dopisz przymiotnik czasownik



b. dopisz przymiotnik

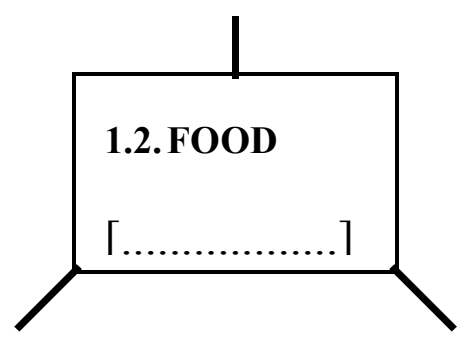

e. dopisz przysłówek

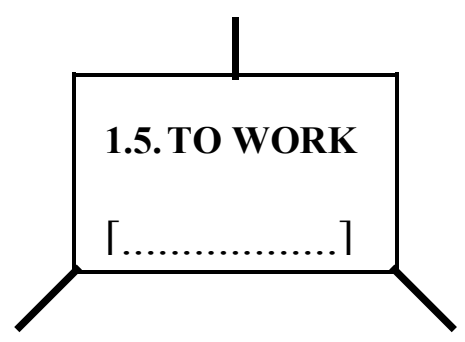

c. dopisz

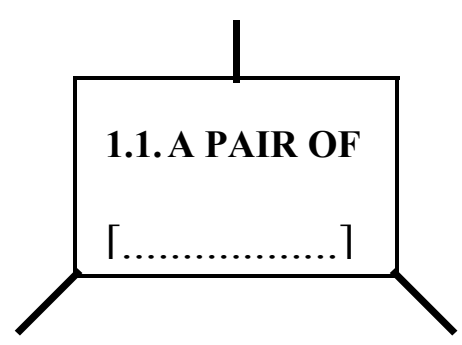

f.

dopisz 
III- circling the correct option

3) Zakreśl właściwą opcję, tak aby zdanie było poprawne.

1. Yesterday after work I went to M1 to $\left|\begin{array}{l}\text { buy } \\ \text { make } \\ \text { do }\end{array}\right|$ the shopping.

2. I wear $\left|\begin{array}{l}\text { casual } \\ \text { common } \\ \text { ordinary }\end{array}\right|$ clothes at work.

3. I have a terrible tooth $\left|\begin{array}{l}\text { pain } \\ \text { discomfort. } \\ \text { ache }\end{array}\right|$

4. I overslept because my alarm clock didn't $\mid \begin{aligned} & \text { turn off. } \\ & \text { set off. } \\ & \text { go off. }\end{aligned}$

5. I bought a $\left|\begin{array}{l}\text { tin } \\ \text { can } \\ \text { mug }\end{array}\right|$ of white paint.

6. You work too $\left|\begin{array}{l}\text { difficult } \\ \text { seriously. } \\ \text { hard }\end{array}\right|$ You should go on holiday.

IV- identifying and correcting errors in the underlined part of the sentence

4) Poniższe zdania w podkreślonych fragmentach moga zawierać błędy. Przy zdaniach poprawnych postaw $\sqrt{ }$, przy błędnych - $\mathbf{X}$, oraz napisz ich poprawną wersję.

1. You never change your brain. You're so stubborn.

2. Leszek Miller, the Polish Prime Minister, is a born leader.

3. For my birthday I got a cook book as a present.

4. My hair has increased too long. It needs cutting.

5. I'm pretty exhausted after working in the garden.

6. You don't need to dress smartly for this party.

7. I'll have a joint of beef for lunch. 
All the instructions were given in Polish to avoid misunderstanding them by the students. In the first two tasks students were also additionally asked to give Polish equivalents of the English words so as to find out if knowing the meaning of a word has something to do with knowing its collocational range. The final question for the students to answer was: 'How long have you been learning English? Have you been learning only at school or also in private lessons?'. All tested students had a similar level of proficiency in English (intermediate) and in class used the same textbook, on which this test was partly based. The following 7 types of lexical collocations were particularly focused upon:

$$
\begin{aligned}
& \mathrm{L} 1=\mathrm{V}+\mathrm{N} \text { [verb }+ \text { noun] e.g. make an appointment } \\
& \mathrm{L} 2=\mathrm{Adj}+\mathrm{N} \text { [adjective }+ \text { noun] e.g. high-heeled shoes } \\
& \mathrm{L} 3=\mathrm{N}+\mathrm{N}[\text { noun }+ \text { noun] e.g. job interview } \\
& \mathrm{L} 4=\mathrm{N}+\mathrm{V} \text { [noun }+ \text { verb] e.g. car breaks down } \\
& \mathrm{L} 5=\mathrm{Adv}+\mathrm{Adj} \text { [adverb }+ \text { adjective] e.g. totally exhausted } \\
& \mathrm{L} 6=\mathrm{Quant}+\mathrm{N} \text { [quantifier }+ \text { noun] e.g. } \text { a swarm of bees } \\
& \mathrm{L} 7=\mathrm{V}+\mathrm{Adv} \text { [verb }+ \text { adverb] e.g. take it seriously }
\end{aligned}
$$

It has been attempted to examine which category of those collocations the students found most

\begin{tabular}{|c|c|c|}
\hline Type of results & $\begin{array}{c}\text { Average } \\
\text { number of } \\
\text { points }\end{array}$ & $\begin{array}{c}\text { Average } \\
\text { percentage of } \\
\text { correct answers }\end{array}$ \\
\hline \multicolumn{3}{|c|}{ GENERAL RESULTS } \\
\hline & $24 / 43$ & $55 \%$ \\
\hline \multicolumn{3}{|c|}{ KNOWNIG THE MEANING VERSUS KNOWING THE COL. RANGE } \\
\hline $\begin{array}{l}\text { THE NUMBER OF CORRECT POLISH } \\
\text { EQUIVALENTS IN EXERCISES } 1 \text { AND } 2\end{array}$ & $21 / 30$ & $71 \%$ \\
\hline $\begin{array}{c}\text { THE NUMBER OF CORRECT WORD } \\
\text { COMBINATIONS IN EXERCISES } 1 \text { AND } 2\end{array}$ & $16 / 30$ & $52 \%$ \\
\hline \multicolumn{3}{|c|}{ RESULTS FROM INDIVIDUAL EXERCISES } \\
\hline EXERCISE 1 & $8 / 12$ & $64 \%$ \\
\hline EXERCISE 2 & $8 / 18$ & $43 \%$ \\
\hline EXERCISE 3 & $4 / 6$ & $72 \%$ \\
\hline EXERCISE 4 & $3 / 7$ & $46 \%$ \\
\hline \multicolumn{3}{|c|}{ RESULTS CONCERNING INDIVIDUAL CATEGORIES OF COLLOCATIONS } \\
\hline L1 & $5 / 8$ & $63 \%$ \\
\hline L2 & $5 / 8$ & $64 \%$ \\
\hline L3 & $2 / 3$ & $57 \%$ \\
\hline L4 & $3 / 7$ & $42 \%$ \\
\hline L5 & $2 / 5$ & $32 \%$ \\
\hline L6 & $3 / 6$ & $55 \%$ \\
\hline L7 & $3 / 6$ & $54 \%$ \\
\hline
\end{tabular}
difficult and troublesome. The level of difficulty of individual exercises is also taken into account owing to the fact that some turned out to be easier than other.

\subsection{The results.}

Global results, which are given as the round average number of points scored by the students and the average percentage of correct answers, are presented in the table below:

Table 1. 
As far as global results are concerned, the students seem to know 55\% of all collocations, scoring on average 24 points out of 43 . More than a half of them ( 31 people) were found above the mean, which is shown in Figure 1 below:



Figure 1 .

What is more, from this chart we can conclude that in this group there is no direct dependence of a student's results on the number of years she/he has been learning English. Some of the students who have been studying for a shorter time scored better, which proves that the efficiency of a second language learning is determined by a number of various factors. In this group most students who have attended optional private lessons (marked with red circles in the chart) were found above the mean.

On the basis of the results from the first two exercises, in which students were additionally asked to give the Polish equivalents of the English words, we can estimate if knowing the meaning of a word helps students to match it with its right collocate. The students knowing the meaning of $71 \%$ English words were able to identify only $52 \%$ of collocations made up of these words. The conclusion is that despite knowing the meanings of both elements of a collocation they did not always succeed in correct matching.

Another observation can be made while analyzing the results from individual exercises. The task the students found the easiest, scoring $72 \%$ of correct answers was exercise 3 which consisted in choosing the right option. The most difficult one turned out to be exercise 2 , in which the students were asked to give 3 optional words which both collocate with the central word and belong to the specified part of speech. The students hardly ever provided all 3 words, which suggests that they find it easier to match two words in a collocation if they are confronted with a group of words to choose from (like in exercise 3) than to think of a group of collocates, even as small as a 3-element one. Even if a student knows the Polish equivalent of the central word, he/she frequently fails to generate its collocates. In some cases the students resorted to their native Polish language and its rules, which resulted in producing incorrect collocations, e.g. *ride a car [jeździć + samochód], which in English is inadmissible, because ride only collocates with horse or bike. Such combinations as: make homework, make the shopping instead of do homework/the shopping, in which both verbs make and do have the same Polish equivalent robić are also prevalent.

The aforementioned 7 categories of lexical collocations were also compared in regard to the degree of difficulty each of them caused. The $\mathrm{L} 1=[\mathrm{v}+\mathrm{n}]$ and $\mathrm{L} 2=[\operatorname{adj}+\mathrm{n}]$ types, which account for $63 \%$ and $64 \%$ of correct answers respectively appear to be the easiest and the best-mastered ones. This fact is clearly noticeable even in exercise 2, which is said to be the most difficult. The L5= 
[adv + adj] collocations, which account only for $32 \%$ of correct answers, as well as the $L 4=[n+v]$ (over 40\%) turned out to be a source of serious trouble.

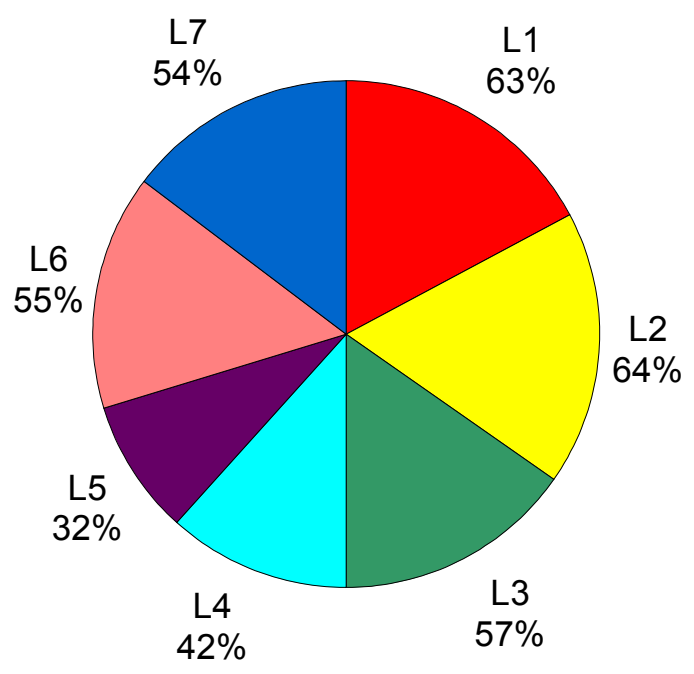

Figure 2.

\section{The role collocations play in the process of second language teaching.}

The role collocations play in second language teaching is integrally related with a concept introduced in the 1970s, according to which language is learned in a series of pre-fabricated blocks or chunks, defined by Lewis [1994] as unanalyzed wholes. These chunks are said to be the basic data, by which learners identify patterns in a language. Previously, this function was attributed to grammar, which was regarded a necessary condition for successful communication. Prendergast (1806-1886) noted that children learn not just words but chunks of a language, which they later use fluently in their speech. These chunks seemed to be so well-mastered that the only possible explanation of this fact was that they had been memorized as complete units. The children can't have known grammatical patterns at this stage so the acquisition of these chunks and their ensuing reconstruction resulted from the previous process of imitation and reiteration. It was not however until over a century later that these observations were appreciated and applied in teaching vocabulary, featuring very largely in the 'lexical approach' theory. This approach diverges from vocabulary traditionally understood as a stock of individual words with fixed meanings and focuses on the fact that recurrent and ready-made word combinations are the integral elements of a learner's lexis and produce most of the learner's texts. Only a minority of spoken sentences are entirely novel creations. Both native speakers and second language learners are more prone to store and retrieve whole chunks rather than create them from scratch. Thus, collocation being a category of such chunks called 'multi-word' items plays a crucial role in acquiring foreign language.

Lewis [1997] in his 'lexical approach' theory points out that fluency in a foreign language is conditioned by the acquisition of a number of pre-fabricated chunks. He also regards collocation as a central feature of a language production. Therefore, students' attention should be fully directed to it. Lewis [2000] also claims that the number of collocations understood as word combinations is greater than the number of all words because the same words can occur in various collocations. That is why collocations pose enormous problems, even for the most proficient in English. Furthermore, grammar rules are too general to be of any help for students judging whether a 
collocation is admissible or not. In consequence, in his view, collocations provide more practical and precise instructions than general grammar rules. Those collocational patterns exemplify some variants which grammar rules do not embrace, e.g. a usually uncountable noun weather can appear in the collocation out in all weathers in plural. As a result, the usage of collocation determines precision and pertinence of the speech. In addition, collocational competence enables students to produce texts which not only are grammatically correct or merely probable or hypothetical but, inter alia, authentic, which means it is this collocation which a native speaker would use in this specific situation. Lewis comes to a conclusion that only by expanding a range of memorized whole word combinations it is possible to achieve proficiency level in mastering the syntax of a second language. Collocations also boost the generation of a learner's lexicon, which is especially true for nouns- every time they are presented in class they should be accompanied by a range of adjectives and verbs which are their collocates. You will not use a noun in a proper context unless you know which words co-occur with it. As a result, knowing a word cannot be limited to merely knowing its meaning; what is crucial is to know it collocational range as well.

Hill [1999] even suggests coining a term 'collocational competence'. Learners have considerable difficulty developing collocational competence unless they are able to collocate words successfully. If in their lexical corpus there are no ready-made chunks at their disposal, they have to generate them from scratch on the basis of grammar rules. This leads to numerous mistakes. A wide range of meaningful chunks and collocations in the learner's mental lexicon makes it possible to quickly find the right word. It also facilitates and accelerates the communication process. Szulc [1984] claims that acquisition of collocations in a second language is fundamental when it comes to gaining language competence. Collocational errors are typical even of proficient learners.

According to Nattinger [1980], language production is based on piecing together ready-made units appropriate for a particular situation. Comprehension of such units depends on knowing the patterns to predict in different contexts. That is why a learner should be instructed in what way and in what cases those units can be combined.

Carter [1987] perceive collocations as crucial factors of lexical coherence and stresses the need of teaching collocation at all levels of language proficiency.

In Celce-Murcia's view, familiarity with the way words combine is a basic, native-like aspect of learning and using vocabulary. This knowledge helps learners to encode and decode the language following the rule that it is easier to unscramble a message if its elements are highly predictable.

The authors of Oxford Collocation Dictionary [2002] also stress the role of collocation in a language, claiming that it runs through the whole of a language to such extent that no piece of natural spoken or written language is totally free of collocation. Every student choosing the right collocation makes his/her speech more natural and more native-speaker-like. What is more, a language that is colloctionally rich is also more precise because the meaning of a word is always determined by the context and it is collocation that provides this context. Thanks to that, learners can express more clearly and, at the same time, more precisely the message they want to convey.

\section{Final conclusions.}

The analysis of the tests carried out among intermediate English learners led to a conclusion that their results support the hypotheses put forward in the 'lexical approach' theory. Learning individual words and their meaning does not suffice to achieve great fluency in a second language. Knowing the way words combine into chunks characteristic of the language is imperative. Consequently, if learners' sensitivity to various relations between words is not heightened enough or words are not learned in chunks, learners are not bound to approach the native-like level of proficiency. Since learners do not have many guidelines to follow while considering the admissibility of collocation, this aspect of every language is very problematic. What must not be underestimated in the process of second language teaching is the role of the teacher and the textbook. From the very beginning, learners' attention should be turned to this kind word combinations and students should be constantly acquainted with an increasing number of collocations. The richer in collocations the learner's lexicon is, the higher precision, accuracy, 
coherence and authenticity of his/her speech. This is a perfect way to fluency and proficiency in the language as well as to greater language competence.

\section{References}

Bahns, J. 1993. Lexical collocations: a contrastive view. ELT Journal, 47(1), 56-63.

Benson, M., Benson, E., \& Ilson, R. 1997. The BBI Combinatory Dictionary of English: A Guide to Word Combinations. John Benjamin Publishing Company

Carter, R. 1987. Vocabulary. Applied Linguistic Perspectives, London and New York: Routledge.

Celce-Murcia, M. 1991. Teaching English As A Second or Foreign Language, Heinle \& Heinle Publishers

Dzierżanowska, H. 1988. Przekład tekstów nieliterackich na przykładzie języka angielskiego, Warszawa: PWN.

Firth, J. R. 1957. Papers in Linguistics, 1934 - 1951, Oxford: OUP.

Firth, J. R. 1957. A Synopsis of Linguistic Theory, 1930-1955 [In:] Studies in Linguistic Analysis.

Gitsaki, C. 1996. The Development of ESL Collocational Knowledge. A thesis submitted for a Phd in the Centre for Language Teaching and Research at The University of Queensland

www.cltr.uq.oz.au:8000/users/christina.gitsaki/thesis/contents.html

Halliday, M. A. K. 1966. Lexis as a linguistic level w C.E. Bazell, J.C.Catford, M.A.K. Halliday \& R.H. Robins (Eds.), In memory of J.R. Firth (148-162). London: Longman.

Hill, J. 1999. Collocational Competence, ETP April 1999 Issue 11

Hoey, M. 2000. A World Beyond Collocation: New Prespectives on Vocabulary Teaching w Teaching Collocation (Eds.) M. Lewis, Hove LTP.

Howatt, A. P. R. 1984. A History of English Language Teaching, Oxford: OUP.

Hunston, S., Francis, G. \& Manning, E. 1997. Grammar and Vocabulary: showing the connections, ELT Journal, Volume 51, Issue 3: July 1997.

Kania, S. \& Tokarski, J. 1984. Zarys leksykologii i leksykografii polskiej, Warszawa: Wydawnictwa Szkolne i Pedagogiczne.

Kjellmer, G. 1990. Patterns of collocability, [In:] J. Aarts i W. Meijs (Eds.) Theory and Practice in Corpus Linguistics, Amsterdam: Rodopi.

Lewis, M. 1994. The Lexical Approach. The State of ELT And A Way Forward, Language Teaching Publications.

Lewis, M. 1997. Implementing the Lexical Approach: Putting Theory into Practice, Hove: Language Teaching Publications

Lewis, M. 2000. Teaching Collocation: Further Development in the Lexical Approach, Hove: Language Teaching Publications

Nattinger, J.R. 1980. A Lexical Phrase Grammar for ESL. TESOL Quarterly, 14(3), 337 - 344.

Oxford Collocations Dictionary For Students of English 2002. Oxford: OUP.

Sinclair, J. 1966. Beginning the Study of Lexis, w C.E. Bazell, J.C. Catford, M.A.K. Halliday and R.H. Robins (Eds.): In Memory of J.R. Firth, Longman.

Sinclair, J. 1991. Corpus Concordance Collocation, Oxford: OUP.

Skorupka, S. 1967. Stownik frazeologiczny języka polskiego, Warszawa: Wiedza Powszechna.

Szulc, A. 1984. Podręczny stownik językoznawstwa stosowanego. Dydaktyka języków obcych, PWN Warszawa.

Lexis. Chapter 4: From Collocation to Colligation. www.kielikanava.com/chap4.html 